\title{
Experimental infection by Borrelia anserina strain PL in Gallus gallus
}

\section{Infecção experimental de Borrelia anserina cepa PL em Gallus gallus}

\author{
Marcio Barizon Cepeda ${ }^{1}$; Matheus Dias Cordeiro ${ }^{2 *}$; Bruna de Azevedo Baêta ${ }^{3}$, \\ Adivaldo Henrique da Fonseca ${ }^{4}$
}

\section{Highlights}

The spirochetaemia is proportional to the appearance of symptoms in avian Borreliosis.

Spirochetaemia based on the direct count of bacteria by a Neubauer chamber.

Avian borreliosis decreased average body weight of animals due to infection.

\begin{abstract}
Avian borreliosis is a tick-borne acute septicemic disease that affects a variety of avian species and is caused by the bacterium Borrelia anserina. The present study aimed to establish the infection dynamics of B. anserina in experimentally infected Gallus gallus to determine its impact on the health and weight gain of the animals. Forty G. gallus were divided into four groups. Group 1 (G1) included 10 animals inoculated intramuscularly (IM) with $250 \mu \mathrm{L}$ of blood serum containing $3.7 \times 106$ spirochetes per milliliter. Group 2 (G2) included 10 animals inoculated IM with $250 \mu \mathrm{L}$ of saline $0.9 \%$. Group 3 (G3) included 10 animals infested with four Argas miniatus nymphs ( $3^{\text {rd }}$ instar) infected with B. anserina strain PL. Group 4 (G4) included 10 animals infested with four $A$. miniatus nymphs ( $3^{\text {rd }}$ instar) free of infection by $B$. anserina. The number of spirochetes in the blood was directly proportional to the appearance of clinical signs and symptoms. This is the first study showing the experimental clinical evolution of the B. anserina PL strain in G. gallus. Additionally, the first assessments of spirochetaemia are presented, based on the direct count of bacteria in the serum by a Neubauer chamber, during the infection.
\end{abstract}

Key words: Chickens. Borreliosis. Argasidae. Brazil.

1 Prof., PhD, Undergraduate Program in Veterinary Medicine, Universidade de Vassouras, Maricá, RJ, Brazil. E-mail: marciobarizoncepeda@yahoo.com.br

2 Prof., PhD, Graduate Program in Practices in Sustainable Development, Universidade Federal Rural do Rio de Janeiro, UFRRJ, Seropédica, RJ, Brazil. E-mail: mathcordeiro@hotmail.com

3 Profa, PhD, Professional Master's Degree in Diagnostic Veterinary Medicine, Universidade de Vassouras, Vassouras, RJ, Brazil. E-mail: babaeta@hotmail.com

4 Prof., PhD., Graduate Program in Veterinary Sciences, UFRRJ, Seropédica, RJ, Brazil. E-mail: adivaldofonseca@ yahoo.com

* Author for correspondence

Received: Oct. 16, 2020 - Approved: Mar. 01, 2021 


\section{Resumo}

Borreliose aviária é uma doença septicêmica aguda transmitida por carrapatos que afeta uma variedade de espécies aviárias e é causada pela bactéria Borrelia anserina. O presente estudo teve como objetivo estabelecer a dinâmica da infecção de $B$. anserina em Gallus gallus experimentalmente infectados e determinar seu impacto na saúde e no ganho de peso dos animais. Quarenta G. gallus foram divididos em quatro grupos. O Grupo 1 (G1) incluiu 10 animais inoculados por via intramuscular (IM) com 250 $\mu \mathrm{L}$ de soro sanguíneo contendo 3,7x106 espiroquetas por mL; Grupo 2 (G2) incluiu 10 animais inoculados IM com 250 $\mathrm{LL}$ de soro fisiológico 0,9\%; Grupo 3 (G3) incluiu 10 animais infestados com quatro ninfas de Argas miniatus ( $3^{\circ}$ instar) infectadas com B. anserina cepa PL. O Grupo 4 (G4) incluiu 10 animais infestados com quatro ninfas de A. miniatus ( $3^{\circ}$ instar) livres de infecção por $B$. anserina. $O$ número de espiroquetas no sangue foi diretamente proporcional ao aparecimento de sinais e sintomas clínicos. Este é o primeiro estudo que mostra a evolução clínica experimental da cepa B. anserina PL em G. gallus. Além disso, são apresentadas as primeiras avaliações da espiroquetemia, baseadas na contagem direta da bactéria no soro por uma câmara de Neubauer, durante a infecção.

Palavras-chave: Galinhas. Argasidae. Borreliose. Brazil.

\section{Introduction}

A tick-borne acute septicemic disease that affects a variety of avian species is caused by the bacterium Borrelia anserina Sakharoff (1891). In Brazil, Labruna, Resende, Martins and Jorge (1999) reported an outbreak of $B$. anserina infection in chickens and demonstrated that a tick of the genus Argas is the biological transmitter. Avian borreliosis has previously been reported as an acute and severe illness that drastically affected the poultry industry and trade of many countries (Aragão 1911; El Nasri, Shigidi, \& Mohammed, 2010; McNeil, Hinshaw, \& Kissling, 1949). This disease is currently restricted to small and medium-sized rustic poultry farms, appearing in the context of both local subsistence and trade (Cepeda et al., 2016; Lisbôa et al., 2008; Lisboa et al., 2009).

Avian borreliosis has a pre-patent period of five to seven days, a patency period of four to six days, and an incubation period of three to eight days (Lisboa et al., 2009). In experimental IM or intravenous (IV) inoculation with blood, the pre-patent period is two days (Ataliba, Resende, Yoshinari, \& Labruna, 2007; Labruna et al., 1999).

The disease is manifested by hyperthermia and polydipsia, drowsiness, inappetence, diarrhea, which can progress to cyanosis with hypothermia, paralytic disorders, and potential death. Previous studies have reported the occurrence of anemia in poultry infected with $B$. anserina (El Nasri et al., 2010; Lisbôa et al., 2008) a hematological change that occurred in parallel with the spirochetemia period, which may evolve to self-healing in some cases (Lisbôa et al., 2008). Common necropsy findings include hepatomegaly with whitish spots and splenomegaly (Boero, 1967; Cepeda et al., 2016). The objective of the present study was to establish the infection dynamics of $B$. anserina in experimentally infected Gallus gallus to correlate its impact on the health and weight gain of the animals. 


\section{Material and Methods}

This study was conducted in accordance with ethical principles of animal experimentation and was approved by the Ethics Committee of the Universidade Federal Rural do Rio de Janeiro (CEUA-IV UFRRJ) for the use of animals under protocol number $123 / 2014$.

A total of 40 female chickens (49 days old) of commercial strain "Redbro Plumé" belonging to the same batch and immune to Marek's disease and avian bouba. The animals were identified using plastic rings on one leg and housed in suspended cages, with two animals per cage.

The animals were divided into four groups: Group 1 (G1), 10 animals inoculated IM with blood serum $(250 \mu \mathrm{L})$ containing $3.7 \times 10^{6}$ spirochetes per microliter (inoculum with two previous blood passages in healthy poultry after being thawed from cryopreservation); Group 2 (G2), 10 animals inoculated IM with $250 \mu \mathrm{L}$ of saline $0.9 \% \mathrm{NaCl}$ (control group "Serum"); Group 3 (G3), 10 animals infested with four Argas miniatus nymphs ( $3^{\text {rd }}$ instar) infected with $B$. anserina strain PL (Ataliba et al., 2007); Group 4 (G4), 10 animals infested with four $A$. miniatus nymphs ( $3^{\text {rd }}$ instar) free of infection by $B$. anserina (control group "Tick"). The protocols of the ticks and serum positives acquired were described in (Cepeda et al., 2016).
Blood samples were collected daily from the infected groups (G1 and G3). A drop of blood was obtained through a light needle puncture in a visible vein on the inside of the wing. The blood was collected using a micro-hematocrit capillary and followed by centrifugation to obtain the serum. The obtained serum was diluted in PBS saline solution (10\% serum) to assist in counting spirochetes. Spirochete concentrations per milliliter were evaluated daily during infection from the first day post-inoculation (DPI) by direct counting in a Neubauer chamber on a phase contrast microscope with $10 x$ and $40 x$ objectives.

Clinical changes such as the color of the mucous membranes, color and consistency of the feces, clinical signs, and the verification of body temperature (with a clinical digital thermometer - Incoterm $^{\circledR}$ ) were observed daily. Animal weights were measured at $0,4,8$, $12,16,20$, and 24 DPI using a portable digital scale with a hook.

\section{Results and Discussion}

Some animals in the infected groups (G1 and G3) revealed spirochetemia, even in the absence of clinical signs characteristic of the disease, which allowed bacterial growth to be measured during infection. The prepatency and patency periods were $2 \pm 0.30$ and $5 \pm 1.38 \mathrm{DPI}$ in $\mathrm{G} 1$, while these periods for G3 were $5 \pm 0.97$ and $5 \pm 1.03$ DPI, respectively (Table 1). 
Table 1

Number of spirochetes in sera of Gallus gallus infected with Borrelia anserina strain PL. G1- animals inoculated IM with blood serum. G3 - animals infested with four Argas miniatus nymphs ( ${ }^{\text {rd }}$ instar) infected with $B$. anserina

\begin{tabular}{|c|c|c|c|c|c|c|c|c|c|c|}
\hline \multirow{3}{*}{ Groups } & \multicolumn{10}{|c|}{ Number of Spirochetes ( $\times 10^{4}$ Spirochetes $/ \mu \mathrm{L}$ ) } \\
\hline & & \multicolumn{9}{|c|}{ Days post-infection } \\
\hline & & $1^{\circ}$ & $2^{\circ}$ & $3^{\circ}$ & $4^{\circ}$ & $5^{\circ}$ & $6^{\circ}$ & $7^{\circ}$ & $8^{\circ}$ & $9^{\circ}$ \\
\hline \multirow{2}{*}{ G1 } & Mean & 0 & 16.53 & 4660 & 3012.50 & 110 & 0 & 0 & 0 & 0 \\
\hline & SD & 0 & 13.16 & 1943.91 & 1411.12 & 149.16 & 0 & 0 & 0 & 0 \\
\hline \multirow{2}{*}{ G3 } & Mean & 0 & 0 & 0 & 0.3 & 5.90 & 291.53 & 1465.50 & 2275 & 0 \\
\hline & SD & 0 & 0 & 0 & 0.64 & 13.39 & 708.07 & 1247.22 & 4725.33 & 0 \\
\hline
\end{tabular}

In G1, spirochetes were visualized from 2 DPI, with spirochetemia being more accentuated in relation to $\mathrm{G} 3$ and reaching its peak at $3 \mathrm{DPI}$. The number of spirochetes dropped sharply from 4 DPI and disappeared at $6 \mathrm{DPI}$. On the other hand, bacterial growth in G3 was delayed when compared to that observed in $\mathrm{G} 1$, with the detection of spirochetes from $4 \mathrm{DPI}$ in three animals; however, detection only occurred at 6 DPI in the remaining groups. The maximum number of spirochetes was observed at $8 \mathrm{DPI}$. After $9 \mathrm{DPI}$, no more spirochetes remained in the blood circulation of the animals.

In G1, some animals already exhibited clinical signs of the disease at $2 \mathrm{DPI}$. All animals exhibited clinical signs after $3 \mathrm{DPI}$, which lasted until $9 \mathrm{DPI}$. At $10 \mathrm{DPI}$, all animals recovered, showing improvements in the consistency of their feces and resuming normal eating.

The animals in G3 showed clinical signs of the disease later than in G1. At 2 DPI, one chicken from $\mathrm{G} 3$ had ruffled feathers presented the same clinical signs and at $5 \mathrm{DPI}$. At 6 DPI, all animals exhibited clinical signs that lasted until $10^{\circ} \mathrm{DPI}$. One animal from G1 and two animals from $\mathrm{G} 3$ died at $5 \mathrm{DPI}$ and 9 DPI, respectively. No animals in the control groups (G2 and G4) showed clinical signs characteristic of the disease.

Daily weights over the course of the infection for the four experimental groups are shown in Figure 1. A decrease in the average body weight of animals in G1 was observed, which lasted until the third weighing (8 DPI). The period in which this marked reduction in body weight in $\mathrm{G} 1$ was observed is compatible with the phase of greater intensity of clinical signs and approached the peak of spirochetemia. In relation to $\mathrm{G} 3$, a decrease was only observed between the second and third weighing (between 4 and 8 DPI). From the fourth weighing on, a progressive weight gain was observed. As predicted, animals in the control groups (G2 and G4) gained weight normally. 


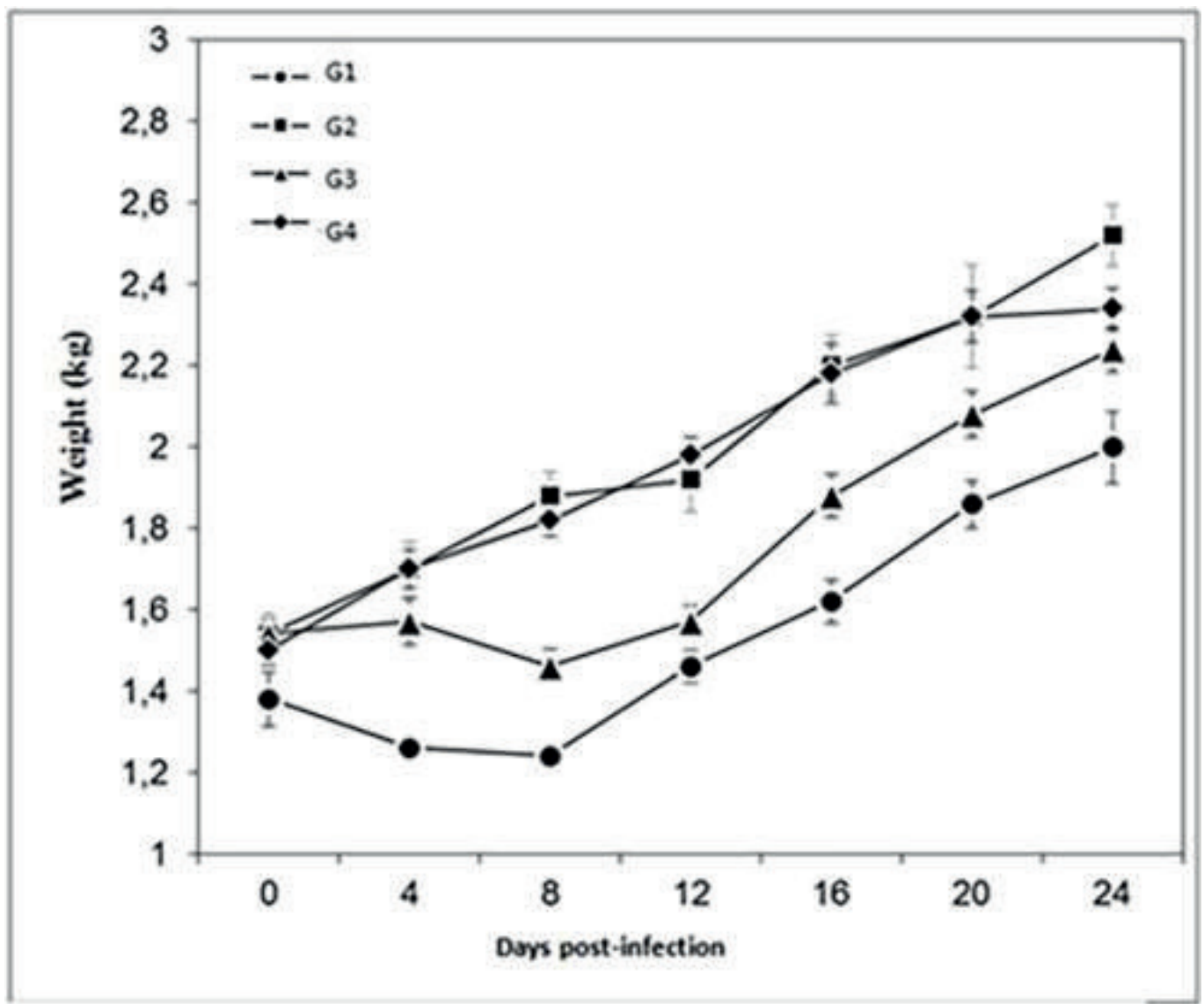

Figure 1. Average weight corporal of Gallus gallus infected with Borrelia anserina strain PL (G1 and G3) and controls groups (G2 and G4), measured daily for 26 days after infection.

Regarding body temperature, the differences between infected groups (G1 and G3) and control groups (G2 and G4) were evident. In $\mathrm{G} 1$, there was an increase in the average body temperature of animals from 1 to $5 \mathrm{DPI}$, which normalized from $6 \mathrm{DPI}$. In relation to $\mathrm{G} 3$, an increase was observed in the interval between 5 and $8 \mathrm{DPI}$, and the temperature normalized (below $42^{\circ} \mathrm{C}$ ) from $9 \mathrm{DPI}$. In $\mathrm{G} 2$ and $\mathrm{G} 4$, the temperature was maintained at normal values throughout the evaluation. Since the clinical digital thermometer could only measure a maximum temperature of 43 ${ }^{\circ} \mathrm{C}$, this value was possibly exceeded during the higher-temperature phase.
This is the first study to show the experimental clinical evolution of the $B$. anserina PL strain in G. gallus. Additionally, the first assessments of spirochetemia are presented based on the direct count of bacteria in the serum using a Neubauer chamber during infection. This evaluation facilitated the observation of spirochetes in the blood being directly proportional to the appearance of clinical signs and symptoms.

In Brazil, the disease was first reported by Marchoux and Salimbeni in 1903, in the State of Rio de Janeiro, studying the development of the disease in naturally infected chickens. 
These authors reported that, after the peak of parasitemia, the spirochetes disappeared completely from the blood circulation of the infected animals, even in those in which their clinical condition was compromised. Therefore, clinical changes found after the acute phase of the disease may progress to hypothermia, paralysis of limbs and wings, followed by death, or spontaneous healing.

In this study, the epidemiological indexes evidenced by the disease, corroborate the findings of Marchoux and Salimbeni (1903), since it was also possible to verify the disappearance of spirochetes from the circulation of birds submitted to the experiment after the acute phase of the infection, being verified in the 6 DPI and 9 DPI, the milestone of these observations in groups $\mathrm{G} 1$ and $\mathrm{G} 3$ respectively.

El Nasri et al. (2010) experimentally studied the pathology of avian borreliosis and observed anorexia, diarrhea, pallor of crest and dewlap, wing paralysis, and ruffled feathers during infection. Notably, similar clinical signs were also observed in the present study.

Shommein and Khogali (1974) and Bandopadhyay and Vegad (1983) reported a pre-patent period of two to four days when serum or blood with $B$. anserina was inoculated in poultry. According to these authors, this short period between inoculation and the appearance of spirochetes may be related to the inoculation route and the concentration of spirochetes in the inoculated serum. Following a microscopic analysis of blood smears from infected chickens through intramuscular inoculation of blood infected with $B$. anserina, Rivetz, Bogin, Weisman, Avidar, \& Hadani (1977) observed a pre-patent period of three days after inoculation with a peak established between 5 and $7 \mathrm{DPI}$. Furthermore, El Nasri et al. (2010) reported the appearance of spirochetes in peripheral blood within 48 hours after the inoculation of serum or citrated blood, which remained in the blood at 4 to 6 DPI, with a peak of parasitemia occurring at 3 DPI. Notably, the pre-patent period observed in the present study was similar to those observed in the aforementioned studies. When it was inoculated with infected $A$. miniatus, a pre-patent period of four to six days was reported (Hutyra, Marek, \& Manninger, 1947), which is similar to the results of the present work. Additionally, Schwan (1996) observed a biological dependence between spirochete and vector, which is essential for conferring the development of pathogenicity to borreliae. The ticks used in the present study were exposed to infection 30 days before the beginning of the experimental procedure, which allowed time for the spirochetes to settle and multiply in the ticks.

The clinical signs were more evident and intense at the beginning of the first and second weeks in $\mathrm{G} 1$ and G3, respectively. These results suggest that the differences observed in relation to the incubation periods for the two groups occurred due to the greater number of spirochetes and the higher speed of bacterial migration observed in G1 (IM inoculation) when compared with G3 (inoculation by ticks). According to Boero (1967), the incubation period is five to eight days when spirochetes are inoculated through the bite of an infected tick. The intensity of clinical signs also coincided with the peak of spirochetemia in the animals.

According to Boero (1967), the initial clinical form of the disease is characterized by intense polydipsia due to the large volume of blood sent to the main irrigation organs such 
as the liver, spleen, kidneys, and intestines. This is in addition to intense drowsiness and lethargy due to the penetration of spirochetes in the brain and spinal cord, which determines a neurotropic character in its parasitemia. In the present study, infections exhibited an acute and septicemic character, which was confirmed by the large number of spirochetes observed in the peripheral blood of groups of infected animals (G1 and G3) and by the tissue lesions produced.

According to Bandopadhyay and Vegad (1983), greenish diarrhea can be observed due to the occurrence of enteritis and hemosiderosis; however, spirochetes disappear from the intestine 96 hours after infection. Additionally, Boero (1967) reported that the greenish color of feces also occurs through bile leakage, which covers the stool intensely. Intestinal absorption and normal peristalsis are also impaired, which contributes to the liquid and/or pasty consistency of the feces. Notably, fecal consistency returns to normal following the clinical cure.

In the present study, the decreased average body weight of animals likely occurred due to the state of prostration and drowsiness caused by the infection, which could result in the animals losing their stimulus and interest in food. According to Lisboa et al. (2009), animals that survived the infection showed an improvement in their physical condition and regained normal weight. Notably, this result was also observed in the present study.

The normal body temperature of poultry varies between 41 and $42{ }^{\circ} \mathrm{C}$ (Welker et al., 2008). However, Boero (1967) reported that the body temperature increase in sick poultries is due to the massive invasion of spirochetes in the blood and its multiplication in the plasma. Boero (1967) also reported that poultry no longer have spirochetes in the bloodstream and a pyretic period is established when their body temperature normalizes. According to the same author, fever produces adynamic or muscle weakness during infection, while spirochetes consume plasma glucose and muscle glycogen stores factors that also contribute to the reduction of body weight in poultry.

\section{Conclusions}

Borrelia anserina infection in poultry can cause serious illnesses by drastically reducing their body development. Weight loss in poultry may result in damage to the organic poultry's industry when infested by $A$. minitaus ticks infected with $B$. anserina.

\section{Acknowledgments}

The authors extend a special thanks to the Coordination for the Improvement of Higher Education Personnel (CAPES) for the scholarship to MBC. We would like to express our gratitude to the National Council for Scientific and Technological Development of Brazil - CNPq (A.H.F. 312169/2017) and Research Support Foundation in the state of Rio de Janeiro - FAPERJ (A.H.F., grant number E 26/203.029/2017), for their financial support.

\section{References}

Aragão, H. B. (1911). Soroterapia e vacinação na espiroquetose das galinhas. Memórias do Instituto Oswaldo Cruz, 3(1), 3-39. doi: 10.1590/S0074-02761911000100001 
Ataliba, A. C., Resende, J. S., Yoshinari, N., \& Labruna, M. B. (2007). Isolation and molecular characterization of a Brazilian strain of Borrelia anserina, the agent of fowl spirochaetosis. Research Veterinary Science, 83(2), 145-149. doi: 10.1016/j. rvsc.2006.11.014

Bandopadhyay, A. C., \& Vegad, J. L. (1983). Observations on the pathology of experimental avian spirochaetosis, Research in Veterinary Science, 35(2), 138-144. doi: 10.1016/S0034-5288(18) 32170-2

Boero, J. J. (1967). Parasitosis animals. Buenos Aires, Argentina: Eudeba.

Cepeda, M. B., Cepeda, P. B., Baêta, B. A., Gaudêncio, F. N., Cordeiro, M. D., Magalhães-Matos, P. C.,... Fonseca, A. H. (2016). Alterações bioquímicas, anatômicas e histopatológicas em fígado de Gallus gallus Linnaeus, 1758 experimentalmente infectados por Borrelia anserina Sakharoff, 1891. Pesquisa Veterinaria Brasileira, 36(8), 687-693. doi: 10.1590/S0100-736X2016 000800002

El Nasri, I. M., Shigidi, M., \& Mohammed, A. M. (2010). Pathology of domestic fowl spirochaetosis in different age groups of chicken experimentally infected with Borrelia anserina. Sudan Journal of Veterinary Research, 25(1), 23-28. Retrieved from http://sudanjvr.net/jour nal/43.pdf

Hutyra, F., Marek, J., \& Manninger, R. (1947). Espiroquetosis de las Aves de corral: Spirochaetosis avium. Barcelona, Espanha: Editorial Labor.
Labruna, M. B., Resende, J.S., Martins, N. R. S., \& Jorge, M.A. (1999). Cryopreservation of an avian spirochete strain in liquid nitrogen. Arquivo Brasileiro de Medicina Veterinaria e Zootecnia, 51(6), 551-553. doi: 10.1590/ S0102-09351999000600008

Lisbôa, R. S., Guedes, D. S., Jr., Silva, F. J. M., Cunha, N. C., Machado, C. H., \& Fonseca, A. H. (2008). Alterações nos parâmetros hematológicos de Gallus gallus domesticus experimentalmente infectados por Borrelia anserina. Pesquisa Veterinária Brasileira, 28(10), 527-532. doi: 10.1590/S0100-736X200 8001000014

Lisboa, R. S., Teixeira, R. C., Rangel, C. P., Santos, H. A., Massard, C. L., \& Fonseca, A. $H$. (2009). Avian spirochetosis in chickens following experimental transmission of Borrelia anserina by Argas (Persicargas) miniatus. Avian Diseaseas, 53(2), 166168. doi: 10.1637/8377-061508-Reg.1

Marchoux, E., \& Salimbeni, A. (1903). La spirillose des poules. Annales de l'Institut Pasteur Lille, 17(1), 569-580.

McNeil, E., Hinshaw, W. R., \& Kissling, R. E. (1949). A study of Borrelia anserina infection (spirochetosis) in turkeys. Journal of Bacteriology, 57(2), 191-206. doi: 10.1128/JB.57.2.191-206.1949/

Rivetz, B., Bogin, E., Weisman, Y., Avidar, J., \& Hadani, A. (1977). Changes in the biochemical composition of blood in chickens infected with Borrelia anserina. Avian Pathology, 6(4), 343-351. doi: 10. 1080/03079457708418244

Schwan, T. G. (1996). Ticks and Borrelia: model systems for investigating pathogen- 
arthropod interactions. Infectious Agents and Disease, 5(3), 167-181. Retrieved from https://europepmc.org/article/med/ 8805079

Shommein, A., \& Khogali, A. (1974). Fowl spirochaetosis haematological and histopathological studies. Bulletin of epizootic diseases of Africa, 22(3), 255261. Retrieved from https://pubmed.ncbi. nlm.nih.gov/4471445/
Welker, J. S., Rosa, A. P., Moura, D. J. D., Machado, L. P., Catelan, F., \& Uttpatel, R. (2008). Temperatura corporal de frangos de corte em diferentes sistemas de climatização. Revista Brasileira de Zootecnia, 37(8), 1463-1467. doi: 10.15 90/S1516-35982008000800018 
